\title{
The Process of Education of OSH Services and Organization Development
}

\author{
Marta Znajmiecka-Sikora • Katarzyna Boczkowska
}

Published online: 19 May 2012

(C) The Author(s) 2012. This article is published with open access at Springerlink.com

\begin{abstract}
Contemporary business is characterised, first and foremost, by quickly growing competition, rapid changes in customer preferences, and constant pressure for innovations and cost effectiveness. That creates a difficult work environment, with occupational safety and health $(\mathrm{OSH})$ management becoming a strategic element in the planning of enterprises' development (compare: Znajmiecka-Sikora et al. 2009, 2010). The article aims to analyse the knowledge, qualifications, and professional competence of OSH service employees - a group that is crucial for maintaining an appropriate safety level in the organisation - in the context of employers' expectations. The study covered 450 OSH service employees working in selected provinces of Poland and was carried out from 2009 to 2010. It used an interview questionnaire composed of 64 items concerning the knowledge, skills, activity in the training market, and flexibility of OSH service employees. The analysis of received results indicates that although OSH service employees hold appropriate qualifications (confirmed by certificates of having undergone appropriate training), they often have insufficient knowledge and skills in the scope of duties imposed on them, hence they are not able to meet the expectations of their employers.
\end{abstract}

Keywords Competences of the OSH service employee - Qualifications of the OSH service employee

JEL M12-Personnel management · Executive compensation

\section{Introduction}

The transformation of Central and Eastern European countries that began at the turn of the 1980s and 1990s caused changes in all areas of Poland's social life. Progress

M. Znajmiecka-Sikora ( $\square)$

Human Resources Development Association, University of Lodz, Lodz, Poland

e-mail: marta.sikora@centrumego.eu

K. Boczkowska

Technical University of Lodz, Lodz, Poland 
taking place in various fields and integration with the European Union set directions for further changes concerning work safety and the approach to the development and improvement of employee competence. Today, people are increasingly considered to be a crucial element on which the success of an organisation depends, and the need for the effective and appropriate development of employees is more important than ever (Znajmiecka-Sikora and Kędzierska 2011). As indicated by the analysis of organisations, they often embrace the concept of learning organisation more and more. That term defines the contemporary organisation as such that is capable of satisfying customer needs and competing in the market thanks to its ability to learn and adapt to changing operating conditions. That is achieved by the organisation (to put it quite simply) through the openness of its employees to new ideas and trends as well as constant improvement and development of its members, structures, and processes that take place in it (Bieńkowska 2009).

As indicated by a study conducted on the group of 4,000 employers, Polish employers have to fulfil numerous requirements specified in a variety of legal provisions in order to offer their employees safe conditions of work. They often get lost in a maze of regulations. With a view of satisfying the safety requirements imposed on them, they engage qualified employees and delegate safety-related tasks to them. At present, Polish employers expect Occupational Safety and Health (OSH) service employees to know applicable legal regulations, be able to prepare required documentation (e.g., OSH instructions), asses occupational risk or draw up a post-accident report, and effectively cooperate with inspection agencies such as the National Labour Inspectorate or the National Sanitary Inspectorate (compare: Znajmiecka-Sikora et al. 2009, 2010). Moreover, several years' professional experience of the authors of this article, who acted in the capacity of expert witnesses or specialists in occupational safety and health, proves that there are numerous irregularities in maintaining safe working conditions by employers, which makes accidents occur. Actions taken by OSH services turned out to be insufficient in the majority of such court cases, and OSH personnel showed an outrageous lack of knowledge when appearing before the courts.

The article aims to analyse the knowledge, qualifications, and professional competences of OSH service employees - a group that is crucial for maintaining an appropriate safety level in the organisation - in the context of employers' expectations.

\section{Occupational Safety and Health Specialist as a Profession}

Conditions to be met in order to enter the profession of Safety and Health Specialist are stipulated by the Regulation of the Council of Ministers of 2 September 1997 on Occupational Safety and Health Services (Journal of Laws No. 109, item 704, as amended). The immediate superior of the OSH service employee in the organisation is his or her employer. Such a position in the organisation chart makes OSH service employees equal to the senior management, which in turn requires them to have very high professional qualifications and competences. 
Qualifications necessary to work as the OSH service employee may be acquired through formal education or lifelong learning (a specialised course of higher studies, postgraduate studies, a qualification course, a vocational/technical secondary school, or post-secondary OSH school). Essential knowledge concerns such issues as legal regulations, ergonomics, occupational risk, development of working methods, threat analysis, and work psychology. Skills include organising and coordinating the work of the employing establishment's OSH services, working out modernisation and development plans for the employing establishment, formulating proposals for meeting the requirements of ergonomics at workstations, offering advice in the scope of applicable occupational safety and health principles and regulations, and cooperating with research institutes and external supervisory agencies interested in OSH-related work conditions. Personal and social competences are mainly communication skills, including persuasive communication, ability to motivate others to behave in a safe way, and organisation of work (compare: Znajmiecka-Sikora and Boczkowska 2011).

In the context of the above competence profile, the following research problem was formulated: OSH service employees, despite their appropriate professional qualifications confirmed by certificates of having completed an OSH education course, do not have sufficient knowledge and skills enabling them to carry out tasks entrusted to OSH services and are incapable of meeting employers' requirements in a professional manner.

The study covered 450 OSH service employees working in selected provinces of Poland - the Lower Silesian province and Lodz province. It was performed from 2009 to 2010 within the framework of projects entitled: "The Analysis and Appraisal of Lower Silesian Enterprises' and OSH Staff's Adaptation to Changes in Regulations and Market Needs" and "The Analysis and Appraisal of Lodz Enterprises' and OSH Staff's Adaptation to Changes in Regulations and Market Needs".

The study applied an interview questionnaire composed of 64 items regarding the knowledge, skills, activity in the training market, and flexibility of OSH service employees.

As no statistically significant differences occurred in analysed study results between the groups of OSH service employees from the Lower Silesian and Lodz provinces, the received results are presented jointly for the entire studied population.

\section{General Description of the OSH Service Employee}

The studied group consisted of $145(32.22 \%)$ females and $305(67.78 \%)$ males. The majority were aged 51-60 (30.67\%). The least numerous group were individuals aged $20-30(n=54 ; 12.00 \%)$ and above 60 , who accounted for $11.56 \%(n=52)$ of the studied group. The largest percentage, i.e., 114 individuals $(25.22 \%)$, had been working as OSH service employees for 6-10 years.

The analysis of the subjects' education level indicates that most of them have higher education - 309 individuals (68.67\% of the studied population), 139-secondary education $(30.89 \%)$, and 2 - basic vocational education $(0.44 \%)$. The respondents acquired knowledge of occupational safety and health mainly through attending a post-secondary vocational OSH school $(n=123 ; 27.33 \%)$ or an OSH qualification course $(n=108 ; 24.00 \%)$. 


\section{Personal Development of OSH Service Employees}

Rapid changes taking place in the contemporary world, introduction of new technologies, machinery, and equipment, and adjusting Polish legislation to the European Union requirements make it necessary for employees to improve their qualifications. It is only the process of constant learning that allows them to hold qualifications and competences necessary to fulfil the expectations of their employers.

The analysis of received study results indicates that over $86 \%$ of the studied group of OSH service employees $(n=389)$ participated in training courses aimed at improving their professional competences in the last 5 years. The average was 3.16 training courses per individual in the last 5 years. The most popular were courses in premedical first aid $(n=211 ; 48.89 \%)$, fire protection $(n=193 ; 42.89 \%)$, occupational risk assessment $(n=160 ; 35.56 \%)$, training methods $(n=143 ; 31.78 \%)$, foreign languages $(n=117 ; 26.00 \%)$, systemic occupational safety and health management $(n=113 ; 25.11 \%)$, and postgraduate studies $(n=104 ; 23.11 \%)$.

As shown by the performed analysis, the OSH service employee is aware of the need for constant development and takes steps to that end. The actual training profile suggests that the primary reason for the respondents to undergo training are changes in the law and EU directives as well as employers' expectations which arise from those changes (compare: Znajmiecka-Sikora et al. 2010).

\section{Knowledge and Skills of the OSH Service Employee}

The analysis of OSH service employees' knowledge of duties imposed on them is an attempt at answering a question about the extent to which the OSH service staff are able to perform their tasks in a professional manner.

The occupational safety and health services enjoy certain rights when carrying out their tasks (compare: Journal of Laws of 1997 No. 109, item 704, as amended). The analysis of relevant study results indicates that OSH service employees often do not know the rights conferred on them and are not able to appropriately define the scope of tasks which they are required to fulfil (compare: Table 1).

Table 1 Structure of respondents' answers concerning OSH services' rights

\begin{tabular}{lc} 
Task & $\begin{array}{c}\text { Number of } \\
\text { respondents }\end{array}$ \\
\hline Conducting inspections of OSH specialists & 431 \\
Requesting to award an employee & 296 \\
Putting forward proposals for threat removal & 368 \\
Requesting to punish an employee & 366 \\
Stopping a machine & 396 \\
Removing an employee from work & 330 \\
Requesting to stop in the employing & 149 \\
establishment or its part & 15 \\
Other: representing the employer in court, & \\
National Labour Inspectorate, Chief & \\
Sanitary Inspectorate &
\end{tabular}


The next key area of research was the scope of tasks entrusted to OSH services. The respondents could choose from among 29 tasks, 18 of which complied with the statutory scope of OSH services' tasks (compare: Journal of Laws of 1997 No. 109, item 704, as amended) and 11 of which exceeded the legal scope. The respondents could make multiple choices.

The received results are divided into correct answers-Table 1 and those inconsistent with the legal requirements-Table 3.

The results presented in Table 2 indicate conclusively that knowledge of the above issues is incomplete among the studied OSH service employees. Regrettably, none of the respondents marked answers reflecting the full scope of statutory tasks by simultaneously rejecting incorrect answers included by the authors in the questionnaire (compare: Table 3). To sum up, it should be stated that the awareness among the OSH service employees of the scope of duties for which the $\mathrm{OSH}$ services were appointed is unsatisfactory. Thus, it can hardly be expected that those employees will always be able to provide their employers with effective assistance.

When testing the OSH services' skills related to occupational risk assessment, which is the principal element of accident prevention, the respondents were asked questions about the manner and documentation of occupational risk assessment.

Table 2 Quantitative and percentage distribution of OSH services' tasks that are consistent with the law both actually and according to respondents

\begin{tabular}{|c|c|c|}
\hline Scope of the OSH services' tasks & $n$ & $\%$ share \\
\hline Monitoring working conditions & 417 & $92.67 \%$ \\
\hline Keeping - drawing up accident documentation & 418 & $92.88 \%$ \\
\hline Conducting post-accident procedures & 414 & $92.00 \%$ \\
\hline Running preliminary, general OSH training courses & 408 & $90.67 \%$ \\
\hline Participating in the OSH committee's works & 408 & $90.67 \%$ \\
\hline Periodic analyses of OSH conditions & 399 & $88.67 \%$ \\
\hline Consultancy related to workstation's organisation in accordance with OSH principles & 394 & $87.56 \%$ \\
\hline Participating in occupational risk assessment & 394 & $87.56 \%$ \\
\hline Participating in OSH consultations & 380 & $84.44 \%$ \\
\hline Cooperation with physician providing preventive health care to employees & 380 & $84.44 \%$ \\
\hline Expressing opinions on detailed OSH instructions & 374 & $83.11 \%$ \\
\hline Putting forward proposals concerning ergonomic requirements for workstations & 370 & $82.22 \%$ \\
\hline Popularising OSH and ergonomics issues & 361 & $80.22 \%$ \\
\hline Putting forward proposals concerning OSH requirements for manufacturing processes & 361 & $80.22 \%$ \\
\hline $\begin{array}{l}\text { Working out and expressing OSH-related opinions on the employing } \\
\text { establishment's modernisation plans }\end{array}$ & 350 & $77.78 \%$ \\
\hline Cooperation with the Social Labour Inspector & 338 & $75.11 \%$ \\
\hline Participation in handing over of new or converted buildings for their use & 292 & $64.89 \%$ \\
\hline Participation in drawing up work regulations, orders, collective labour agreements etc. & 274 & $60.88 \%$ \\
\hline $\begin{array}{l}\text { Other: cooperation with Chief Sanitary Inspectorate, the supervisory authorities, } \\
\text { and Ministry of Interior }\end{array}$ & 18 & $4.00 \%$ \\
\hline
\end{tabular}


Table 3 Quantitative and percentage distribution of OSH services' tasks inconsistent with the law but right according to respondents

\begin{tabular}{lcc}
\hline Scope of the OSH services' tasks & $n$ & $\%$ share \\
\hline Supervising the observance of OSH principles and regulations & 398 & $88.44 \%$ \\
Supervising working conditions & 320 & $71.11 \%$ \\
Implementing the OSH management system & 228 & $50.66 \%$ \\
Running periodic OSH training courses & 160 & $35.56 \%$ \\
Responsibility for OSH conditions in the employing establishment & 130 & $28.89 \%$ \\
Referring to preventive medical examinations & 128 & $28.44 \%$ \\
Running training courses concerning specific workstations & 118 & $26.22 \%$ \\
Making measurements of the work environment, e.g. noise, dust, & 114 & $25.33 \%$ \\
$\quad$ lighting measurements etc. & 108 & $24.00 \%$ \\
Drawing up system documentation & 106 & $23.55 \%$ \\
Purchase of means of individual protection & 52 & $11.55 \%$ \\
Accountability to the National Labour Inspectorate, the & & \\
National Sanitary Inspectorate, andthe court in OSH issues & \\
\hline
\end{tabular}

The analysis of received study results shows that the subjects associate occupational risk assessment and its documentation mostly with the identification of threats occurring at the workstation. Almost $3 / 4$ of the respondents $(n=$ $337 ; 74.89 \%)$ considered dangerous, harmful, or onerous factors to be the key element of risk assessment documentation. Only half of the interviewees $(n=226$; $50.22 \%$ ) know that the documentation should contain workstation description. The majority $(n=235 ; 52.22 \%)$ do not remember to indicate necessary preventive measures to reduce risks and just a fraction of OSH service employees $(n=22$; $4.88 \%$ ) check whether the documentation stipulates the date of assessment and composition of the occupational risk assessment team. A few more individuals stated that the documentation ought to include names of employees whom the assessment concerns $(n=38 ; 8.44 \%)$, while some of them said that it is necessary to collect employees' signatures. The subjects indicated other elements of the occupational risk assessment documentation such as: results of measurements of the work environment, description of an employed method, specification of an acceptable risk level, and invoking relevant legal provisions. They also gave such peculiar answers as: entire work, procedures, inspection results, and assessment of OSH conditions.

Only ten of the studied OSH service employees (2.22\% of the studied group) marked all elements of the occupational risk assessment documentation required by the law. One out of four respondents $(n=95)$ selected one element: either workstation description or identification of threats. $55.00 \%$ of the interviewees chose two or three items by adding to the above-mentioned ones risk evaluation/assessment for each factor and the indication of preventive measures to counteract identified threats.

Unfortunately, as shown by the study, the OSH service employees are insufficiently prepared to perform their role in such a crucial area as occupational risk assessment. Even if they actually make the assessment, its documentation is bound to be incomplete. 
As the scope of tasks of the OSH service personnel includes "participation in drawing up $[\ldots]$ general instructions concerning occupational safety and health [...], expressing opinions on detailed instructions concerning occupational safety and health at particular workstations" (Journal of Laws of 1997 No. 109, item 704, as amended, §2.1. point 9), they ought to know what kind of instructions, manuals, and plans the employer is obliged to make available to employees for everyday use. They should also know the content of properly prepared workstation instructions.

It seems that the studied OSH service employees marked instructions, manuals, and plans to be prepared in employing establishments in quite a random manner (compare: Table 4). Regrettably, only 15 respondents $(3.33 \%)$ knew that in some cases, instructions on the handling of harmful and dangerous materials should be drawn up and only three $(0.67 \%)$ were aware of the fact that instructions on the use of means of individual protection are also needed. None of the subjects knew about requirements concerning safety signs and signals or measures connected with the storage of dangerous materials.

OSH service employees also lacked knowledge of the content of instructionsonly half of the respondents knew the right content of workstation instructions, i.e., actions before, during, and after work.

In sum, one can have an impression that, despite their declarations that they participate in preparing appropriate instructions, manuals, and plans, the OSH staff usually purchase ready-made, widely-available OSH templates and face great difficulties in drawing up on their own workstation instructions or operating manuals for machinery and equipment that meet legal requirements. Taking into account the extent of the interviewees' ignorance, it seems quite likely that even if instructions are actually prepared, they are incomplete in many a company, hence, they can hardly serve their preventive function.

During the study it was also verified whether the OSH service employees are able to properly identify the type of work performed by employees. That knowledge is indispensible as, in the case of performance of especially dangerous work, special precautions ought to be taken. Moreover, such work requires special supervision.

Table 4 Types of instructions/manuals/plans to be made available by employers to employees for everyday use according to respondents

\begin{tabular}{lrr}
\hline Types of instructions/manuals/plans & $n$ & $\%$ share \\
\hline General OSH instructions & 216 & $48.00 \%$ \\
Workstation instructions & 212 & $47.11 \%$ \\
Operating manuals for machinery and equipment & 196 & $43.56 \%$ \\
Fire prevention plans & 160 & $35.56 \%$ \\
First aid manuals & 140 & $31.11 \%$ \\
Instructions on handling harmful and dangerous materials & 15 & $3.33 \%$ \\
Instructions on conduct in case of accident & 9 & $2.00 \%$ \\
Instructions on the use of means of individual protection & 3 & $0.67 \%$ \\
Instructions concerning safety signs and signals & 0 & $0.00 \%$ \\
Instructions on storing, packing, loading, and transporting dangerous materials & 0 & $0.00 \%$ \\
\hline
\end{tabular}


The analysis of study results indicates that more than $3 / 4$ of the subjects know that one type of especially dangerous work is work at height. The second to be mentioned by the subjects $(n=234,52.00 \%)$ was work in reservoirs and canals. Although, along with especially dangerous works provided for in the abovementioned regulation, the respondents were also able to list other ones regulated by separate provisions $(n=72 ; 16.00 \%)$, only five subjects $(1.11 \%)$ demonstrated complete knowledge in that scope.

The received results show that the OSH services insufficiently identify extremely dangerous work. The ignorance about minimum OSH standards to be maintained is such that, in principle, it prevents the OSH service employees from serving their comprehensive advisory role.

Within the framework of their duties, OSH service employees are obliged to draw up and submit to the employer annual periodic analyses of occupational safety and health with proposals for technical and organisational measures to be taken in order to prevent threats to the life and health of employees and improve conditions of work (Journal of Laws of 1997 No. 109, item 704, as amended). Therefore, it was checked whether the subjects knew how often that should be done (compare: Table 5).

Regrettably, only $76.92 \%(n=340)$ of the respondents were able to give the right answer. While the answers of $10.18 \%$ of them $(n=45)$, stating that the analyses of OSH conditions should be performed quarterly or semi-annually, were obviously inconsistent with legal regulations, they do not pose a serious danger, and hopefully result from raised standards maintained by those individuals. However, the answers of the other 15 subjects, saying that such analyses should be made once every 2 or 5 years indicate a significant gap in their knowledge.

In order to identify the activities of the studied OSH services, selected areas of enterprises' operations to be supervised by them were tested. The respondents were asked several questions about their employers' operations. Taking into account the aim of the study, it was important to determine the level of interest in those operations among the studied OSH service employees.

It can be concluded that the subjects passed the test. A small group of several respondents $(n=10 ; 2.22 \%)$ admitted their ignorance about the appointment of individuals responsible for pre-medical aid administration or evacuation procedures. A few more, i.e., $8.88 \%$ of the interviewees $(n=40)$, do not have any idea about whether their employers take appropriate preventive measures to reduce threats occurring in the work environment.

Table 5 Distribution of answers concerning statutory frequency of $\mathrm{OSH}$ analyses to be performed in enterprises

\begin{tabular}{lr}
\hline How often? & $\%$ share \\
\hline Once a year & $76.92 \%$ \\
Twice a year & $6.33 \%$ \\
Once every five years & $0.68 \%$ \\
quarterly & $10.18 \%$ \\
I do not know & $3.17 \%$ \\
Once every two years & $2.71 \%$ \\
\hline
\end{tabular}




\section{Final Conclusions}

The presented analysis is the first step towards answering the question about the qualifications and competences of OSH service employees in the context of employers' expectations. As already mentioned in the Introduction, the studies concerning employers indicate that they have specific expectations about the role to be served by OSH service employees. The employer expects the potential employee to demonstrate competence allowing him or her to effectively perform OSH tasks, have experience of cooperation with institutions supervising the organisation, and hold additional qualifications and licences enabling him or her to combine several functions. Furthermore, the OSH service employee is expected to constantly develop his or her competence so that they meet requirements specified by the law (compare: Znajmiecka-Sikora et al. 2009, 2010).

It is worth emphasising that the educational system makes an effort to meet employers' expectations as it allows to acquire the OSH service employee's qualifications in both the formal education and lifelong learning systems available at every stage of human life. However, opportunities to study do not equal the high quality of education. As indicated by the performed analyses of received study results, despite their significant participation in various kinds of training, the OSH service employees do not have sufficient knowledge of numerous aspects or competences that would enable them to effectively perform their tasks, hence satisfying employers' expectations.

The low level of knowledge among the interviewees was proved by the analysis of their opinions on the scope of tasks and duties to be performed by the OSH staff in the employing establishment. Although a considerable number of the respondents were right about their role of conducting inspections of OSH conditions, carrying out post-accident procedures, keeping post-accident documentation, and running general OSH training courses, regrettably, almost as many of them believed that their statutory tasks include supervising working conditions, and over $1 / 4$ claimed that they are responsible for OSH conditions in the company. It can hardly be expected that, having such incomplete knowledge, OSH service employees will be able to diligently fulfil tasks for which they were appointed.

The process of occupational risk assessment and the manner of risk documentation are incorrect. In their work, the subjects focus on threat identification, while they forget about taking preventive measures and informing employees whom those issues actually concern.

The majority of the respondents did not properly select instructions, manuals, and plans applicable in employing establishments, in whose preparation and appraisal they should take part. To make matters worse, only one out of two respondents knew how to properly draw up workstation instructions.

The interviewees were unable to properly classify especially dangerous types of work which the majority of them associated solely with work at height. They also did not know OSH requirements for work entailing special dangers, and thus, they could be hardly expected to effectively assist their employers in dealing with such risks.

In the context of the presented study results, the crucial issue seems to be the need to evaluate the quality of education and adjust syllabi for OSH service employees to 
the needs and expectations of employers. A solution may also be to test the competences of OSH service employees through periodic exams to check their skills.

While working on the educational profile, it may be worth drawing on the experience of the European Union, where institutions were established whose task is to react to changes that occur when a new profession is created or when there are considerable modifications in practising an already existing one. They do that by setting new, adequate standards for such a profession. The United Kingdom may be an example. In that country, an institution responsible for the descriptions of professions is composed of academics specialising in relevant fields of study, employers, and representatives of a given profession. Such a group of experts determine the educational profile, by taking into account the needs of the market and expectations of employers.

Poland has no tradition of such analyses and discussions. At the same time, there are no appropriate professional associations that might influence occupational safety and health syllabi and ensure that they satisfy employers' needs.

Open Access This article is distributed under the terms of the Creative Commons Attribution License which permits any use, distribution, and reproduction in any medium, provided the original author(s) and the source are credited.

\section{References}

Bieńkowska, D. (2009). Rozwój zawodowy jako wartość [Professional development as a value]. In A. Kuźniak (Ed.), Vademecum trenera [Trainer's handbook] (pp. 13-24). Cracow: Księgarnia Akademicka [Academic Bookshop] Kraków.

Regulation of the Council of Ministers on Occupational Safety and Health Services (Journal of Laws of 1997 No. 109, item 704, as amended).

Znajmiecka-Sikora, M., \& Boczkowska, K. (2011). Proces kształcenia pracowników służb BHP w kontekście Krajowych Ram Kwalifikacji i wymagań rynku pracy [The process of education of OSH staff in the context of the National Qualifications Framework and requirements of the labor market]. In M. Znajmiecka-Sikora, B. Kędzierska, \& E. Roszko (Eds.), Podstawy kształcenia ustawicznego od A do Z. Kompetencje pracowników a współczesne potrzeby rynku pracy [The basics of lifelong education from A to Z. Employees' competencies and contemporary labour market] (pp. 101-122). Łódź: Wydawnictwo EGO [EGO Publishing House].

Znajmiecka-Sikora, M., \& Kędzierska, B. (2011). Kompetencje jednostki, a efektywność zawodowa [The individual's competences and professional performance]. In M. Znajmiecka-Sikora \& B. Kędzierska (Eds.), Podstawy ksztatcenia ustawicznego od A do Z. Psychologiczne metody wspierania rozwoju osób dorostych [The basics of life-long learning from A to Z. Psychological methods of supporting adults' development] (pp. 17-32). Łódź: Wydawnictwo EGO [EGO Publishing House].

Znajmiecka-Sikora, M., Boczkowska, K., Niziołek, K., \& Sikora, A. (2009). Analiza i ocena stopnia dopasowania dolnoślaskich przedsiębiorstw i kadr bhp do zmian w przepisach i potrzebach rynku. Raport z badań [The analysis and appraisal of Lower Silesian enterprises' and OSH staff's adaptation to changes in regulations and market needs. Study report]. Łódź: Wydawnictwo EGO [EGO Publishing House] p. 94-135.

Znajmiecka-Sikora, M., Boczkowska, K., Niziołek, K., \& Sikora, A. (2010). Analiza i ocena stopnia dostosowania łódzkich przedsiębiorstw i kadr bhp do zmian w przepisach i potrzebach rynku. Raport $z$ badań. [The analysis and appraisal of Lodz enterprises' and OSH staff's adaptation to changes in regulations and market needs. Study report]. Łódź: Wydawnictwo SATORIDRUK [SATORIDRUK Publishing House] p. 153-231. 